\title{
Correction to: Engaging Faith-Based Communities for Rural Coastal Resilience: Lessons from Collaborative Learning on the Chesapeake Bay
}

\author{
Christine D. Miller Hesed ${ }^{1}$ (D) Elizabeth R. Van Dolah ${ }^{1}$ (D) $\cdot$ Michael Paolisso $^{1}$ \\ Published online: 19 February 2020 \\ (C) Springer Nature B.V. 2020
}

\section{Correction to: Climatic Change. https://doi.org/10.1007/s10584-019-02638-9}

The original article has been corrected. Unfortunately the article was initially published online with an incorrect title.

Publisher's Note Springer Nature remains neutral with regard to jurisdictional claims in published maps and institutional affiliations.

The online version of the original article can be found at https://doi.org/10.1007/s10584-019-02638-9

Christine D. Miller Hesed

christinedm@gmail.com

1 Department of Anthropology, University of Maryland, 4302 Chapel Drive, College Park, MD, USA 